\title{
REMODELING OF THE DUCT SYSTEM OF THE RAT SUBMANDIBULAR SALIVARY GLANDS IN CHRONIC ETHANOL INTOXICATION
}

DOl: $10.36740 /$ WLek202001125

\author{
Kostyantyn V. Shevchenko, Galina A. Yeroshenko, Olena V. Vilkhova, Denis R. Kramarenko, Olena S. Yakushko, \\ Anastasiya I. Yachmin \\ UKRAINIAN MEDICAL STOMATOLOGICAL ACADEMY, POLTAVA, UKRAINE
}

\begin{abstract}
The aim: To determine the dynamics of changes in metric parameters of the duct system of rat submandibular glands in normal conditions and chronic ethanol intoxication. Materials and methods: 50 albino outbred rats were involved in the experiment. 10 animals were assigned in the control group, 40 animals - in the experimental group. Animals were sacrificed on 5, 9, 12 and 30 days by overdose of thiopental anesthesia. Pieces of the submandibular glands were embedded into epon-812 according to the conventional technique.

Results: 0 n day 5 of the experiment the lumen diameter of intercalated duct reduced by $9,15 \%(\mathrm{p}<0,05)$. The lumen diameter of the striated ducts was by $5,29 \%$ significantly greater than the values in controls $(p<0,05)$. The lumen diameter of the granular ducts reduced by $2,45 \%(p<0,05)$. On day 30 of the experiment the height of the epithelial cells of the intercalated ducts was by $8,47 \%$ significantly less $(p<0,05)$, the height of the epithelial cells of the striated ducts was by $12,27 \%$ less $(p<0,05)$ and the height of the epithelial cells of the granular ducts was by $11,96 \%$ less $(p<0,05)$ than the values in controls.

Conclusions: No recovery of parameters occurs by day 30 of the experiment, indicating the depletion of the secretory epithelium of the duct system, due to dystrophic changes caused by vascular disorder in the microvasculature.
\end{abstract}

KEY WORDS: salivary gland, duct, rats, ethanol

\section{INTRODUCTION}

Major salivary glands are located outside the oral cavity, and enter it via the excretory ducts [1]. The system of the excretory ducts of the salivary gland lobes consists of intercalated, striated and collecting excretory ducts $[1,2]$. Intercalated ducts located between the acini and striated ducts. They are lined by the low-cuboidal or flattened epithelial cells with a poorly expressed organelle apparatus. Epithelial cells with clear cytoplasm are characterized by the presence of dense granules with mucoid secretion on the apical part of the cell [3]. According to the foreign publications, these granules are more often found in the cells of the ducts, adjacent to the acini. The outer layer of cells in the intercalated ducts is formed by the fusiform myoepithelial cells. Noteworthy, intercalated ducts contain cambial elements of the acini and the system of excretory dusts [4]. These elements are differentiated into the glandular cells or duct cells, enabling regeneration of above mentioned parts of the glands [5].

Striated ducts are presented in the form of wide tubules, lined by oxyphilic highly prismatic cells with orbicular centric nuclei. Apical part of the cell protrudes into the wide lumen and lined by short microvilli. It accumulates the secretory granules, which mainly contain kallikrein [6]. G.A. Yeroshenko reports that it is precisely these cells that are involved in the development of a number of substances and growth factors that are secreted by human salivary glands. Importantly, in rodents, and above all, in rats, these and other biologically active substances are produced more actively than in humans [7]. In the lobules of the rat submandibular glands, secretory granules in the epithelial cells of the granular ducts contain kallikrein and ensure local mechanisms for regulating blood flow to the vascular system of the salivary glands [8]. Salivary glands produce the saliva, which plays a significant role in maintaining the homeostasis of the oral cavity $[9,10]$. Recently, the interest of researchers in the study of the patterns of the salivary glands response to various stimuli has increased significantly, which is due to the diagnostic value of saliva as a highly informative object for the clinical assessment of the state of the overall health [11].

The World Health Organization reports about 2.5 million alcohol-related deaths worldwide, accounting for $4 \%$ of all deaths, and alcohol is a causative factor for general illness and injuries. Currently, the alcohol situation in Ukraine is quite devastating. [12,13]. Chronic ethanol intoxication is manifested by a wide range of effects of various negative factors on the body. Currently, alcohol remains one of the most common toxic factors in everyday life. [14].

Objectification of the findings of the study is achieved by the morphometric method, which enables detection 


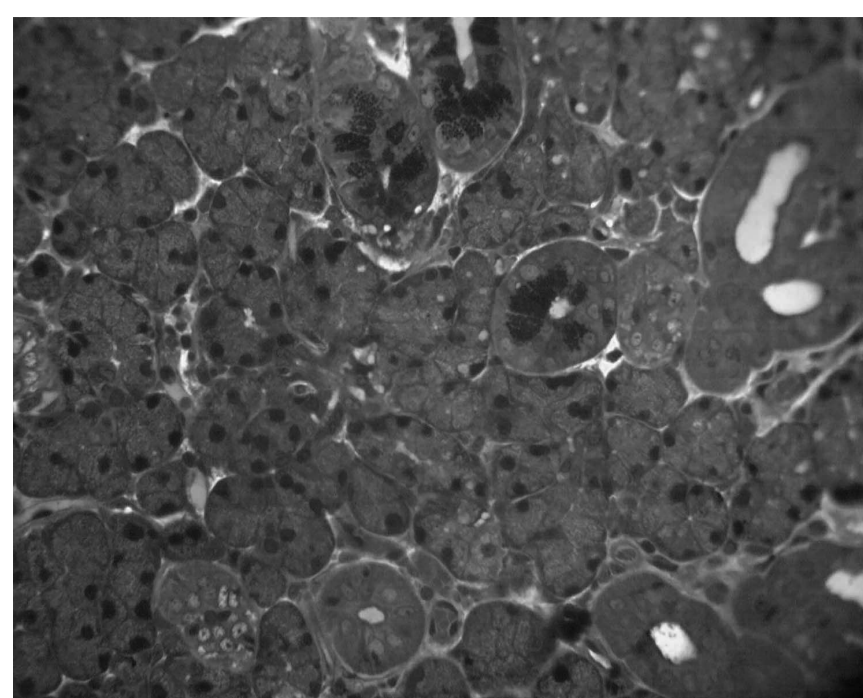

Fig. 1. Intercalated duct of the parenchyma of the lobule of the rat submandibular gland on day 9 of the experiment. Semi-thin section. Methylene blue stain. 400×magnification.

of changes in the structural elements of organs after the effect of various endogenous and exogenous factors [15].

\section{THE AIM}

The paper was aimed at the determination of the dynamics of changes of metric parameters of the duct system of the rat submandibular glands in normal condition and chronic ethanol intoxication.

\section{MATERIALS AND METHODS}

50 albino outbred rats were involved in the experiment. 10 animals were assigned in the control group and were administered with isotonic saline solution QID, delivered directly into the stomach. 40 animals were assigned in the experimental group, who were administered with $12 \mathrm{mg} / \mathrm{kg}$ ethanol $40^{\circ}$ QID, delivered directly into the stomach [16]. Animals were withdrawn from the experiment on day 5, 9,12 and 30 by thiopental anesthesia overdose $(25 \mathrm{mg} /$ $\mathrm{kg}$ ). Pieces of the submandibular glands were embedded into epon-812 according to the conventional technique [17]. Semi-thin sections were stained with methylene blue. The mean values of the outer diameter, the diameter of the lumen of the ducts and the height of the epithelial cells were determined using a Biorex-3 BM-500T microscope with a digital microphotohead DCM with software, adapted to these studies. Statistical processing of morphometric data was performed using the Exel program [18]. Animal housing and experiments on them have been carried out in compliance with the "General Ethic Rules for Conducting Experiments on Animals", adopted by the I National Congress on Bioethics and the requirements of international principles of the "European Convention for the Protection of Vertebrate Animals Used for Experimental and Other Scientific Purposes" [19].

\section{RESULTS AND DISCUSSION}

Morphometric study of the intercalated ducts of the submandibular glands of rats of control group has established that their outer diameter was $18,68 \pm 1,07 \mu \mathrm{m}$ and the lumen diameter was $3,28 \pm 0,02 \mu \mathrm{m}$. The height of the epithelial cells was $7,08 \pm 0,07 \mu \mathrm{m}$ (Table I).

On day 5 of the experiment the outer diameter of the intercalated ducts reduced by $9,04 \%$ compared to the controls $(\mathrm{p}<0,05)$. The lumen diameter reduced by 9,15 $\%$. The height of the epithelial cells was $7,06 \pm 0,04 \mu \mathrm{m}$, showing no significant difference from the parameters in the controls $(p<0,05)$ (Table I).

On day 9 of the experiment it was established that the value of the outer diameter of the intercalated ducts of the rat submandibular glands no significant difference from the findings of the previous time period of the experiment $(\mathrm{p}<$ $0,05)$; however, it was by $11,64 \%$ less than the values in the controls. The lumen diameter of the intercalated ducts reduced by $1,34 \%$ compared with the day 5 of the experiment, though was significantly less by $10,37 \%$ compared with the values in controls $(p<0,05)$. The height of the epithelial cells reduced by $4,96 \%$ compared with the day 5 of the experiment that was significantly less by $5,22 \%$ compared with the values in controls $(\mathrm{p}<0,05)$. Its mean values were $6,71 \pm 0,06 \mu \mathrm{m}$ (Table I).

The wall of the intercalated duct was formed by the cuboidal cells with basophilic cytoplasm and eccentric nucleus; the lumen of the duct was narrowed (Fig. 1).

On day 12 the outer diameter of the intercalated ducts was by $12,74 \%$ significantly less than the values in controls $(\mathrm{p}<0,05)$. The lumen diameter enlarged by $3,74 \% \mathrm{com}-$ pared with the values of day 9 ; however, it was by $7,01 \%$ less than the value in controls $(\mathrm{p}<0,05)$. The height of the epithelial cells reduced by $1,19 \%$ compared with the values of day 9 of the experiment and was by $6,63 \%$ significantly less than the values in control rats $(\mathrm{p}<0,05)$ (Table I).

Table I. Morphometric parameters of the intercalated ducts of the submandibular glands ( $\mu \mathrm{m})$

\begin{tabular}{|c|c|c|c|}
\hline Intercalated ducts & Outer diameter & Lumen diameter & Height of the epithelial cells \\
\hline Control group & $18,68 \pm 1,07$ & $3,28 \pm 0,02$ & $7,08 \pm 0,07$ \\
\hline Day 5 & $16,99 \pm 1,05 *$ & $2,98 \pm 0,02 *$ & $7,06 \pm 0,04$ \\
\hline Day 9 & $16,58 \pm 1,03 *$ & $2,94 \pm 0,01 *{ }^{* * *}$ & $6,71 \pm 0,06 * * *$ \\
\hline Day 12 & $16,30 \pm 1,03 *$ & $3,05 \pm 0,01 *{ }^{* * *}$ & $6,63 \pm 0,04 *{ }^{* * *}$ \\
\hline Day 30 & $16,18 \pm 1,04 *$ & $3,06 \pm 0,01 *$ & $6,48 \pm 0,05 * * *$ \\
\hline
\end{tabular}

Note: ${ }^{*}-p<0,05$ compared to the controls; ${ }^{* *}-p<0,05$ compared with the previous time period of observation. 


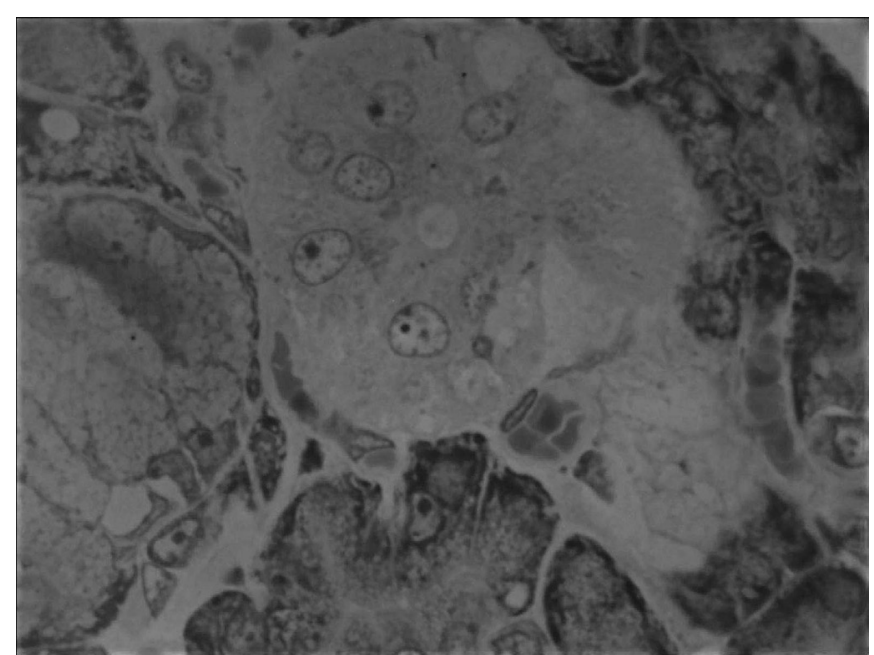

Fig. 2. Striated duct of the lobules of the rat submandibular gland on day 12 of the experiment. Methylene blue stain. 1000×magnification.

On day 30 of the experiment the outer diameter of the intercalated ducts of the submandibular glands differed insignificantly from the value of the previous time period of the experiment and was by $13,38 \%$ significantly less than the values in control animals $(\mathrm{p}<0,05)$. Similarly, the lumen diameter differed insignificantly from the value on day 12 of the experiment, though was by $6,71 \%$ significantly less than the findings in controls $(\mathrm{p}<0,05)$. The height of the epithelial cells was by $2,26 \%$ less than the values in the previous time period of the experiment and by $8,47 \%$ significantly less than the values in controls $(\mathrm{p}<0,05)$ (Table I).

The morphometry of the striated ducts of the submandibular glands of rats of control group has established that their outer diameter was $34,80 \pm 2,05 \mu \mathrm{m}$ and the lumen diameter was $5,10 \pm 0,03 \mu \mathrm{m}$. The height of the epithelial cells was $14,43 \pm 1,07 \mu \mathrm{m}$ (Table II).

On day 5 of the observation the outer diameter of the striated ducts enlarged insignificantly. The mean value of the lumen diameter was by 5,29\% significantly greater than the values in controls. The height of the epithelial cells was almost similar to the values in control rats $(\mathrm{p}<0,05)$ (Table II).

On day 9 of the experiment the values of the outer diameter of the striated ducts of the submandibular glands did not differ from the values of the previous time period of the experiment and its values in controls $(p<0,05)$. The lumen diameter changed insignificantly compared with the values of the previous time period of the experiment; however, it was by $6,67 \%$ significantly greater than the values in controls $(\mathrm{p}<0,05)$. The height of the epithelial cells was by $10,26 \%$ significantly greater than the values in control animals $(\mathrm{p}<0,05)$ (Table II).

On day 12 of the experiment the outer diameter of the striated ducts of the submandibular glands reduced by $11,54 \%$ compared with the previous findings of the experiment and differed insignificantly from the values in control rats $(\mathrm{p}<0,05)$. The lumen diameter enlarged by $2,02 \%$ compared with day 9 and was by $8,82 \%$ significantly greater than its value in controls $(p<0,05)$. The height of the epithelial cells of the striated ducts of the submandibular glands was by $12,88 \%$ significantly less than the findings of day 9 of the experiment with no significant difference from the values in controls $(\mathrm{p}<0,05)$. (Table II).

The wall of the striated duct was formed by the clear epithelial cells. The nuclei were centric. Vacuoles were not numerous. The cytoplasm was homogenous. The basal striation was poorly identified (Fig. 2).

On day 30 of the experiment the outer diameter of the striated ducts was with no significant difference from the values of the previous time period of the observation and values in controls ( $\mathrm{p}<0,05)$. The lumen diameter enlarged by $2,16 \%$ compared with day 12 of the experiment and was by 11,18 $\%$ significantly greater than the values in controls $(\mathrm{p}<0,05)$. The height of the epithelial cells of the striated ducts of the submandibular glands was by $8,66 \%$ significantly less than the values of the previous time period and by $12,27 \%$ less than the values in control animals $(p<0,05)$ (Table II).

The wall of the striated ducts was formed by the highly prismatic cells. The lumen of the ducts of rat submandibular glands was filled with optically clear secret. In the basal segments of the epithelial cells of the striated ducts vacuole-like extensions were visualized that become larger in size during the experiment (Fig. 3).

Morphometric study has established that the mean values of the outer diameter of the granular ducts of rats of control group were $38,38 \pm 0,05 \mu \mathrm{m}$, the lumen diameter was $8,56 \pm 0,06 \mu \mathrm{m}$, and the height of the epithelial cells was $15,47 \pm 0,43 \mu \mathrm{m}$ (Table III).

On day 5 of the experiment the outer diameter of the granular ducts of the submandibular glands differed insignificantly from the values in control rats, whereas the lumen diameter reduced by $2,45 \%$. The height of the epithelial cells was by $12,61 \%$ greater than the values in control group of animals $(\mathrm{p}<0,05)$. On day 9 of the experiment

Table II. Morphometric parameters of the striated ducts of the submandibular glands ( $\mu \mathrm{m})$

\begin{tabular}{cccc}
\hline Striated ducts & Outer diameter & Lumen diameter & Height of the epithelial cells \\
\hline Control group & $34,80 \pm 2,05$ & $5,10 \pm 0,03$ & $14,43 \pm 1,07$ \\
\hline Day 5 & $37,12 \pm 2,11$ & $5,37 \pm 0,04 *$ & $15,76 \pm 1,06$ \\
\hline Day 9 & $37,61 \pm 1,94$ & $5,44 \pm 0,05 *$ & $15,91 \pm 1,09 *$ \\
\hline Day 12 & $33,27 \pm 1,81^{* *}$ & $5,55 \pm 0,05^{* * *}$ & $13,86 \pm 1,09 * *$ \\
\hline Day 30 & $33,48 \pm 1,72$ & $5,67 \pm 0,03 * *^{* *}$ & $12,66 \pm 1,09 *,^{* *}$ \\
\hline
\end{tabular}

Note: ${ }^{*}-p<0,05$ compared to the controls; ${ }^{*}-p<0,05$ compared with the previous time period of observation. 


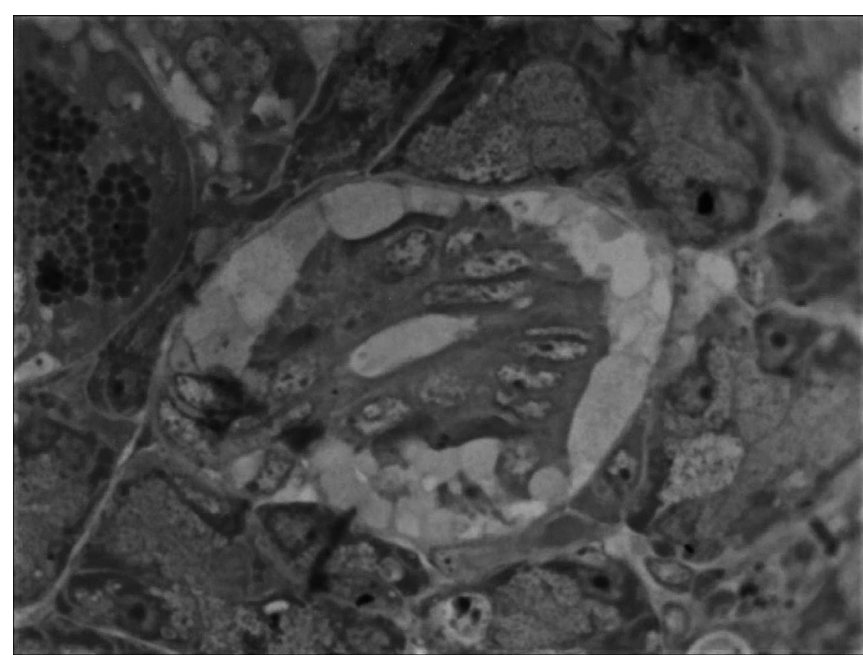

Fig. 3. Vacuoles in the basal part of the epithelial cells of the striated duct on day 30 of the experiment. Semi-thin section. Methylene blue stain. $1000 \times$ magnification.

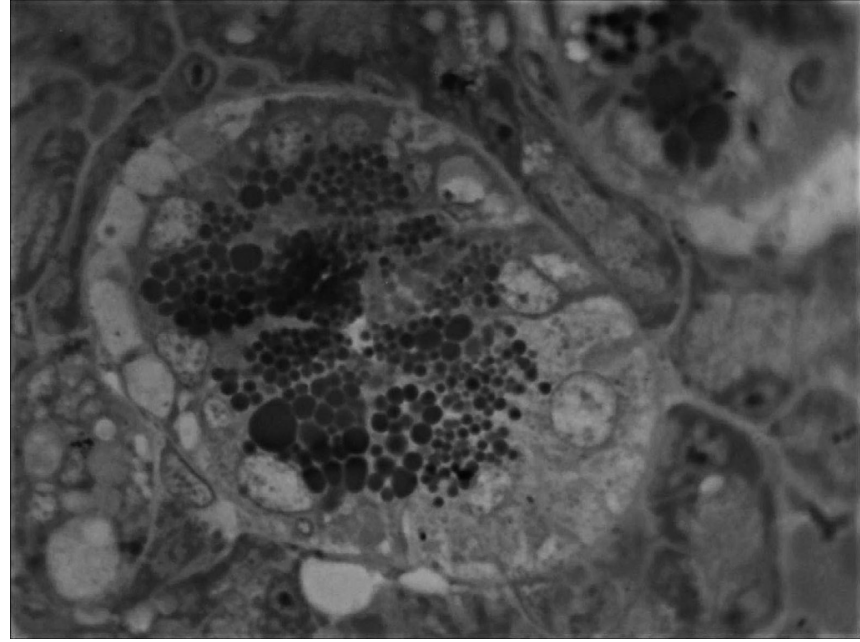

Fig. 4. Granules in the epithelial cells of the granular ducts in the lobules of the rat submandibular glands on day 12 of the experiment. Semi-thin section. Methylene blue stain. $1000 \times$ magnification.

Table III. Morphometric parameters of the granular ducts of the submandibular glands ( $\mu \mathrm{m})$

\begin{tabular}{cccc}
\hline Granular ducts & Outer diameter & Lumen diameter & Height of the epithelial cells \\
\hline Control group & $38,38 \pm 0,05$ & $8,56 \pm 0,06$ & $15,47 \pm 0,43$ \\
\hline Day 5 & $39,31 \pm 0,10$ & $8,35 \pm 0,08^{*}$ & $17,42 \pm 0,36^{*}$ \\
\hline Day 9 & $41,19 \pm 0,17^{* * * *}$ & $9,07 \pm 0,09^{* * * *}$ & $17,91 \pm 0,54^{*}$ \\
\hline Day 12 & $45,23 \pm 0,17^{*}, * *$ & $9,83 \pm 0,08^{* * *}$ & $18,52 \pm 0,46^{* * *}$, \\
\hline Day 30 & $33,58 \pm 0,05^{* * * *}$ & $9,36 \pm 0,07^{* * * *}$ & $13,62 \pm 0,35^{*},{ }^{* *}$ \\
\hline
\end{tabular}

Note: ${ }^{*}-p<0,05$ compared to the controls; ${ }^{* *}-p<0,05$ compared with the previous time period of observation.

the mean value of the outer diameter of the granular ducts of the rat submandibular glands was by $4,78 \%$ greater than the values on day 5 and by $7,32 \%$ greater than the values in controls $(\mathrm{p}<0,05)$. The lumen diameter was by $8,62 \%$ greater than the values of the previous time period of the experiment and by $5,96 \%$ greater than the findings in the control group of animals. The height of the epithelial cells was differed insignificantly from the values of the previous time period of the experiment; however it was by $15,03 \%$ significantly greater compared with findings in controls $(\mathrm{p}<0,05)$. On day 12 of the experiment the outer diameter was by $9,81 \%$ significantly greater than the values on day 9 and by $17,85 \%$ greater than the values in controls $(\mathrm{p}<0,05)$. The mean value of the lumen diameter was by $8,38 \%$ greater than the values of the previous time period of the experiment and by $14,84 \%$ greater than the values in control group of animals $(p<0,05)$. The height of the epithelial cells was by $3,41 \%$ greater than the value on day 9 of the experiment and by $19,72 \%$ significantly greater than the findings in control rats $(\mathrm{p}<0,05)$ (Table III).

The wall was formed by the single layer of the secretory columnar epithelial cells of variable size and amount that contained optically dense basophilic granules in the cytoplasm. In the basal segments of the epithelial cells of the granular ducts the vacuole-like extensions were visualized. The eccentric nuclei were located in the basal segment of the epithelial cells (Fig. 4).
On day 30 of the experiment the mean value of the outer diameter of the granular ducts of the rat submandibular glands was by $25,76 \%$ significantly less than the values on day 12 and by $12,51 \%$ less than the value in controls ( $\mathrm{p}<0,05)$. The lumen diameter also reduced by $4,78 \%$ compared to day 12 and enlarged by $9,35 \%$ compared with controls $(p<0,05)$. The height of the epithelial cells of the granular ducts of the submandibular glands was by $26,46 \%$ less than the value in the previous time period of the experiment and by $11,96 \%$ less than the findings in controls $(\mathrm{p}<0,05)$ (Table III).

The previous experiments showed multidirectional response of the duct system on the state of salivary glands under the influence of various exogenous factors. In that case, on day 14 of the experiment under the effect of methacrylate the mean values of the outer diameter and lumen diameter of the intralobular ducts decreased, tending to reduce in size to the end of the experiment, which was the result of hyperhydration of the amorphous substance due to microcirculation disorder [20], in contrast to the effect of ethanol, when similar changes occurred in the intercalated ducts, which also responded by persistent narrowing with reduce in the height of the epithelial cells due to microcirculation disorder in the exchange section, which is confirmed by the reduced outer diameter by $19.5 \%$, lumen diameter by $12.5 \%$ and thinning of the vascular wall by $30.4 \%$, [21], which resulted in hyposalivation, since intercalated ducts regulate the quantitative aspect of salivation. 
Noteworthy, the mean values of the outer and inner diameters of the striated and granular ducts increased with the subsequent regeneration, due to the compensatory reaction to the narrowing of the intercalated ones to increase the amount of saliva through the juxtacellular transport of liquid from the surrounding interstitium on the side of the striates ducts [9] and the provision of system of local mechanisms for regulating blood flow to the vascular system due to granular ducts with kallikrein granules, leading to depletion of the epithelial cells of the duct system of the submandibular salivary glands at the end of the experiment. It was confirmed experimentally by a decrease in the mean values of the height of the epithelial cells compared to the values in control group of rats, though tending to recovery since ethanol is a metabolite in contrast to methacrylate, which acts as a toxic substance, and the location of the submandibular glands outside the oral cavity, affected indirectly through the vessels of the microvasculature.

\section{CONCLUSIONS}

To conclude with, the duct system responds to the effect of chronic ethanol intoxication, which at the initial stage of the experiment is confirmed by the narrowing of the outer and inner diameters with reduced height of the epithelial cells of the intercalated ducts, enlargement of the outer and inner diameter with increased height of the epithelial cells of the striated and granular ducts with a tendency to regeneration in the second half of the experiment. However, no recovery of the parameters by day 30 of the experiment was registered, which obviously indicates the depletion of the secretory epithelium of the duct system, due to dystrophic changes caused by vascular disorder in the microvasculature, confirmed by changes in the diameters of the walls of the ducts with a decrease in the height of epithelial cells.

\section{REFERENCES}

1. Yeroshenko GA, Shevchenko KV, Kramarenko RD et al. Suchasni uiavlennia pro strukturno-funktsionalnu orhanizatsiiu slynnykh zaloz [Modern concepts of salivary glands structural and functional organization]. Bulletin of Problems Biology and Medicine. 2018;3(145):50-58. (in Ukrainian).

2. Amano 0 . The salivary gland: anatomy for surgeons and researchers. Jpn. J. Oral Maxillofac. Surg. 2011;57:384-393.

3. Amano 0, Mizobe K, Bando Y et al. Anatomy and Histology of Rodent and Human Major Salivary Glands. Acta Histochem Cytochem. 2012;45(5):241-250.

4. Purwanti N, Tsuji D, Azlina A et al. Induction of Sca-1 in the duct cells of the mouse submandibular gland by obstruction of the main excretory duct. J. Oral Pathol. Med. 2011;40:651-658.

5. Bayar N, Kaymaz FF, Apan A et al. Effects of electrohydraulic extracorporeal shock wave lithotripsy on submandibular gland in the rat: electron microscopic evaluation. Int J Pediatr Otorhinolaryngol. 2002;63:223-233.

6. Yeroshenko GA, Lysachenko OD, Shepitko VI. Ultramikroskopichna kharakterystyka posmuhovanykh protok pidiazykovykh zaloz shchuriv pislia vvedennia atsetylkholinu [Ultramicroscopic characteristics of the striated ducts of rat's submandibular gland after acetylcholin injection]. World of Medicine and Biology. 2007;1:14-17. (in Ukrainian).
7. Yeroshenko GA. Ultramikroskopichna kharakterystyka epiteliotsytiv pryvushnoi zalozy shchuriv pislia vvedennia atsetylkholinu [Ultramicroscopic characteristics of epithelial cells of rat's parotid gland after acetylcholin injection]. Achievements of Clinical and Experimental Medicine. 2007;2 (7):81-83. (in Ukrainian).

8. Yerochenko GA, Tsukanov DV, Shepitko IV. Morfometrychna kharakterystyka slynnykh zaloz shchuriv pislia vvedennia prozerinu i platyfilinu [Morphometric description of rats' salivary glands after proserinum and platyphyllinum injection]. World of Medicine and Biology. 2011;3:7-10. (in Ukrainian).

9. Yeroshenko GA, Shepitko VI, Chaikovskyi YuB. Slynni zalozy. Histofiziolohiia stymulovanoi sekretsii [Salivary gland. Histophysiology of stimulated secretion]. Poltava: SPD F0 Kulibaba SV; 2014. 152 p. (in Ukrainian).

10. Yeroshenko GA, Shevchenko KV, Kramarenko RD et al. Strukturnofunktsionalni osoblyvosti slynnykh zaloz zmishanoi sekretsii [Structuralfunctional features of salivary glands of mixed secretion]. Bulletin of Problems Biology and Medicine. 2019;2(149):30-34. (in Ukrainian).

11. Tarasenko LM, Neporada KS. Zalezhnist metabolichnykh zmin u tkanynakh slynnykh zaloz vid stresostiikosti shchuriv [Dependence of metabolic changes in tissues of salivary glands on stress resistance of rats]. Medical Chemistry. 2004;3(6):82-84. (in Ukrainian).

12. Yeshchenko AV. Alkohol u pidlitkovomu vitsi — medychna y sotsialna problema [Alcohol in adolescence is a medical and social problem]. Medical and social problems of family. 2013;18(1):122-126. (in Ukrainian).

13. Kvasha YeA. Kachestvennyie i kolichestvennyie harakteristiki potrebleniya alkogolya v muzhskoy populyatsii i in dinamika: dannyie epidemiologicheskogo issledovaniya [Quality and quantity characteristics of alcohol consumption in male population and their dynamics: data from the epidemiological surveys]. Ukrainian Journal of Cardiology. 2012;3:86-90. (in Russian).

14. Belov AA. Toksicheskoe dejstvie alkogolya na krov. Eritrocity i alkogol [Toxic effect of alcohol on the blood. Erythrocytes and alcohol]. Herald of Almaty State Institute of Advanced Education. 2013;4:75-78. (in Russian).

15. Yeroshenko GA, Kostilenko Yu.P,Skripnikov NS et al. Analiz koreliatsiinykh zviazkiv mizh morfometrychnymy pokaznykamy velykykh slynnykh zaloz shchuriv v normi i pislia stymuliatsii peryferychnoi nervovoi systemy [Analysis of cross-correlation connections between the morphometric indexes of major salivary glands of rats in a norm and after stimulation of the peripheral nervous system]. World of Medicine and Biology. 2009;3(I):64-69. (in Ukrainian).

16. Yeroshenko GA, Shevchenko KV, Yakushko OS. Morphometric characteristics of rat salivary glands hemomicrovasculature capacity component under normal conditions and in ethanol chronic intoxication. World of Medicine and Biology. 2018;3 (65):149-152.

17. Bahriy MM, Dibrova VA, Popadynets $\mathrm{OH}$ et al. Metodyky morfolohichnykh doslidzhen. [Methodology of morphological studies] Bahriy M.M., Dibrova V.A. redaktory. Vinnytsya: Nova knyha; 2016. 328 p. (in Ukrainian).

18. Lapach SN, Chubenko AV, Babich PN. Statisticheskie metody v medikobiologicheskih issledovanijah s ispol'zovaniem Exel [Statistical methods in biomedical research using Excel]. Kiev: Morion; 2000. 320 p. (in Russian).

19. European convention for the protection of vertebrate animals used for experimental an others scientific purposes/Strasbourg: Council of Europ, 1986. № 123.52p. 
20. Stechenko LO, Ivleva YuV, Senchakovich YuV. Reaktsiia protokovoi systemy pidnebinnykh zaloz shchuriv na vvedennia metakrylatu [Rat palatal glands duct system response on input of methacrylate]. World of Medicine and Biology 2015;3(52):127-130. (in Ukrainian).

21. Shevchenko KV, Yeroshenko GA, Yakushko OS et al. Morphometric description of the exchange segment of microvasculature of rats salivary glands in normal conditions and chronic ethanol intoxication. Wiadomości Lekarskie 2019;72( 3):323-326.

The paper has been written within the research scientific work, entitled "Experimental and morphological study of the effect of transplantants of cryopreserved placenta and other exogenic factors on the morphofunctional state of several internal organs"; State registration number 0113 U006185.

\section{ORCID and contributionship:}

Kostyantyn V. Shevchenko - 0000-0003-1665-3236 ${ }^{D}$

Galina A. Yeroshenko - 0000-0003-4279-485X ${ }^{F, E}$

Olena V. Vilkhova - 0000-0002-3371-9930 A

Denis R. Kramarenko - 0000-0001-9837-8762

Olena S. Yakushko - 0000-0001-6247-340X ${ }^{B}$

Anastasiya I. Yachmin - 0000-0002-1829-7610 C

\section{Conflict of interest:}

The Authors declare no conflict of interest

\section{CORRESPONDING AUTHOR Olena S. Yakushko \\ Ukrainian Medical Stomatological Academy Shevchenko 23 str., 36011, Poltava, Ukraine tel: +380662990448 \\ e-mail: olena.yakushko@gmail.com}

Received: 21.04.2019

Accepted: 05.11.2019

A - Work concept and design, B - Data collection and analysis, C - Responsibility for statistical analysis, D-Writing the article, $\mathbf{E}$-Critical review, $\mathbf{F}$ - Final approval of the article 